NBER WORKING PAPER SERIES

\title{
ENVIRONMENTAL CONCERN AND THE BUSINESS CYCLE: THE CHILLING EFFECT OF RECESSION
}

\author{
Matthew E. Kahn \\ Matthew J. Kotchen \\ Working Paper 16241 \\ http://www.nber.org/papers/w16241
NATIONAL BUREAU OF ECONOMIC RESEARCH
1050 Massachusetts Avenue
Cambridge, MA 02138 \\ July 2010
}

We are grateful to Anthony Leiserowitz of the Yale Project on Climate Change for generously sharing survey data used in Section 3 of this paper. We also thank Samantha Go and Aubrey Michi for valuable research assistance. The views expressed herein are those of the authors and do not necessarily reflect the views of the National Bureau of Economic Research.

NBER working papers are circulated for discussion and comment purposes. They have not been peerreviewed or been subject to the review by the NBER Board of Directors that accompanies official NBER publications.

(C) 2010 by Matthew E. Kahn and Matthew J. Kotchen. All rights reserved. Short sections of text, not to exceed two paragraphs, may be quoted without explicit permission provided that full credit, including (C) notice, is given to the source. 
Environmental Concern and the Business Cycle: The Chilling Effect of Recession

Matthew E. Kahn and Matthew J. Kotchen

NBER Working Paper No. 16241

July 2010

JEL No. E32,Q54

\begin{abstract}
$\underline{\text { ABSTRACT }}$
This paper uses three different sources of data to investigate the association between the business cycle-measured with unemployment rates-and environmental concern. Building on recent research that finds internet search terms to be useful predictors of health epidemics and economic activity, we find that an increase in a state's unemployment rate decreases Google searches for "global warming" and increases searches for "unemployment," and that the effect differs according to a state's political ideology. From national surveys, we find that an increase in a state's unemployment rate is associated with a decrease in the probability that residents think global warming is happening and reduced support for the U.S to target policies intended to mitigate global warming. Finally, in California, we find that an increase in a county's unemployment rate is associated with a significant decrease in county residents choosing the environment as the most important policy issue. Beyond providing the first empirical estimates of macroeconomic effects on environmental concern, we discuss the results in terms of the potential impact on environmental policy and understanding the full cost of recessions.
\end{abstract}

Matthew E. Kahn

UCLA Institute of the Environment

Department of Economics

Department of Public Policy

Box 951496

La Kretz Hall, Suite 300

Los Angeles, CA 90095-1496

and NBER

mkahn@ioe.ucla.edu

Matthew J. Kotchen

School of Forestry \& Environmental Studies

Yale University

195 Prospect Street

New Haven, CT 06511

and NBER

matthew.kotchen@yale.edu 


\section{Introduction}

This paper investigates the relationship between environmental concern and the business cycle. The fact that both have undergone such remarkable changes in recent years provides a unique opportunity to evaluate how economic conditions affect public opinion about the environment, which in turn has implications for the likely passage of new environmental policies and the implementation of those that already exist. It is well-known that the end of 2007 was the beginning of the most significant economic downturn in the United States since the Great Depression. Throughout much of 2008 and 2009 gross domestic product (GDP) experienced negative growth, and unemployment rates are now more than double what they were only four years ago. At the same time, we have witnessed a substantial erosion in public concern about environmental issues. Polling results from the Pew Research Center (2009) on what has become the headline issue of climate change, for example, indicate that between April 2008 and October 2009, the percentage of Americans believing in solid evidence that the earth is warming decreased from 71 to 57 percent (a decline of 14 percent); and those thinking climate change is a very serious problem decreased from 44 to 35 percent (a decline of 9 percent).

In this paper we investigate how changes in economic conditions-proxied with unemployment rates—affect three different indicators of environmental concern. We first use data on keyword searches through the internet as complied by Google Insights. Researchers are beginning to use these data as a leading indicator of what issues the public is concerned about; for example, keyword searches for "swine flu” in specific areas at specific points in time are being used as predictors of actual flu activity (Pelat et al. 2009; Valdiva and Monge-Carella 2010). ${ }^{1}$ Recent studies have also shown that Google searches are a powerful tool for predicting

\footnotetext{
${ }^{1}$ Maps that show search trends for the flu and how they are used to predict actual flu activity worldwide are available at http://www.google.org/flutrends/.
} 
economic activity such product demand for automobiles, home sales, retail sales, and travel behavior (Choi and Varian 2009). Using panel data by month for each state, we find that an increase in a state's unemployment rate is associated with a decrease in keyword searches within the state for "global warming” and an increase in searches for "unemployment.” We also find that in more Democratic leaning states, the decline in global-warming searches is larger, but the increase in unemployment searches is smaller.

The second part of our analysis also takes place at the state level and is based on two waves of a survey conducted by the Yale Project on Climate Change in October 2008 and January 2010. The surveys were based on a national sample and were designed to gauge public opinion about climate change. We take advantage of questions that were asked in both waves of the survey, which enables estimation of pooled cross-sectional models that include a variable for the state unemployment rate, controls for respondent characteristics, and state fixed effects. The main results indicate that an increase in a state's unemployment rate is associated with a decrease in several areas of concern related to climate change, ranging from whether respondents think global warming is happening to whether the government should be doing more or less to address the problem.

The third part of our analysis focuses at the county level in California and is based on the Public Policy Institute of California’s (PPIC) monthly survey from 2008 and 2009. The survey question of interest is one that asks residents to choose which issue among a given set is the most important facing California at the time of the survey. One of the possible choices is “environment,” among others related to the economy, education, health, immigration, etc. Merging these data with county-level unemployment rates by month, we estimate a multinomial logit model that takes advantage of the pooled monthly cross sections and controls for 
respondent characteristics. We find that respondents who live in counties featuring a higher unemployment rate are less likely to prioritize the environment. Based on estimates from a linear probability model that controls for county fixed effects, we also find that an increase in the unemployment rate decreases the probability that a respondent chooses the environment as the most important issue.

Together, these three sets of results reveal a strong association between local business cycles, as proxied by state and county unemployment rates, and concern about environmental issues in general and climate change in particular. Each piece of evidence that we present has advantages and limitations, both of which we discuss in more detail later in the paper. But the general pattern is clear: higher unemployment rates—at least when levels reach those observed during the recent recession-erode public concern about the environment.

While there is a sizable literature on public opinion about the environment, we are not aware of any studies using comparable data sets that investigate the influence of macroeconomic trends. Instead, much of the research is focused on how environmental concern is shaped by demographic characteristics (e.g., van Liere and Dunlap 1980, Elliot et al. 1997), political party affiliation (e.g., Dunlap et al. 2008), international differences (e.g., Bloom 1995), and media coverage (e.g., Shanahan et al. 1997). Other studies have examined the influence of environmental public opinion on public policy (e.g., Dunlap 1995). ${ }^{2}$ More related to our study, because it considers a macro-economic variable, is a paper by Elliot et al. (1997) that finds evidence of a positive correlation between per capita disposal income and survey questions about whether respondents think more spending should be allocated toward improving and protecting

\footnotetext{
${ }^{2}$ See Dunlap and Mertig (1992) for a book with several contributed chapters focusing on various trends in environmental concern in the United States.
} 
the environment. Caution should be taken when interpreting these results, however, as they are based on a time series of only 38 data points representing national averages.

Beyond the literature on public opinion, the results of this paper are important for both public policy and economics. Political scientists argue that economic conditions exert a strong influence on public opinion about regulation, because more expensive regulatory efforts are considered more feasible during good times (Vogel 1989). A more nuanced argument is that favorable economic conditions promote support for more liberal policies, whereas tougher economic conditions promote support for more conservative policies (Durr 1993). What is more, beyond environmental issues, it is well established that changes in public opinion have a significant impact on public policy (Page and Shapiro 1983; Burstein 2003). Hence a better understanding of how the business cycle affects environmental concern is important for understanding how environmental policies are ultimately passed, funded, and implemented.

The paper also contributes to the literature on the cost of recessions. While much attention is given to costs related to consumption, real estate, health, and labor, the environmental costs of recessions have gone unrecognized. ${ }^{3}$ Environmental policies are designed, in principle, to correct market failures typically due to negative externalities and the under-provision of public goods. Environmental policies thus have welfare benefits. It follows that if recessions reduce levels of environmental concern, which we find, a further consequence based on existing research is that environmental policies are likely to receive less funding and new environmental legislation is less likely to pass. A specific example of how recessions can impact implementation of environmental policy is the upcoming ballot initiative (Proposition 23) in California to delay the state's climate-change policy (AB32) until the unemployment rate is

\footnotetext{
${ }^{3}$ Environmental benefits may also occur during recessions, perhaps most importantly because of lower pollution emissions due to diminished economic activity (Kahn 1999; Chay and Greenstone 2003).
} 
reduced below 5.5 percent. ${ }^{4}$ Regardless of whether existing environmental policies become less effective or fewer new policies pass, there are welfare consequences that should be accounted for when delineating and/or estimating the costs of recessions. ${ }^{5}$ An important step in this process is to understand the relationship between recessions and environmental concern.

The remainder of the paper is organized as follows. The next three sections present separately our analyses on Google keyword searches, the national survey on public opinion about climate change, and the California survey about priority issues. Section 5 concludes with a summary, a discussion of policy implications, and directions for future research.

\section{Google Keyword Searches}

Google Insights is a publically available online tool for tracking aggregate Google search activity over time for specific geographic areas such as states. ${ }^{6}$ As discussed previously, recent research shows that Google search terms are a powerful tool to predict public health epidemics and economic activity. Here we use Google searches to investigate how changes in the business cycle affect internet search activity related to environmental concern. In particular, we use Google Insights to create a weekly database from January 2004 through February 2010 of searches for two words—-"global warming” and "unemployment”-by state. The basic idea is to analyze how changes in a state's unemployment rate affect search activity for these two keywords. We hypothesize that increases in a state's unemployment rate will result in fewer searches for

\footnotetext{
${ }^{4}$ See http://ag.ca.gov/cms attachments/initiatives/pdfs/i902_initiative_09-0104.pdf.

${ }^{5}$ Cross-national comparisons find evidence of a "J" curve for environmental regulation, whereby more wealthy nations enact more laws to protect the environment (Seldon and Song 1995; Hilton and Levinson 1998). When considering the environmental cost of recessions due to existing laws becoming less effective and fewer new laws being enacted, one should think about a domestic "J" curve and the dynamic welfare implications of moving up and down on it due to recessionary effects.

${ }^{6}$ Google Insights is available at http://www.google.com/insights/search/\#.
} 
“global warming.”7 We also hypothesize that increases in a state’s unemployment rate will increase searches for "unemployment.”

The data available on Google Insights is not the actual number of keyword searches, but rather a scaled variable that enables relative comparisons of trends through time within a keyword and also between keywords. For purposes of our analysis, we standardize the search frequency data by keyword and by state. This means that the search data is distributed $N[0,1]$ for each keyword over time within each state. We follow this procedure because our identification strategy is based on variation within a state, and the uniform scaling facilitates comparison of magnitudes between the different keywords of global warming and unemployment. ${ }^{8}$ With these weekly internet search data we merge corresponding monthly state unemployment data from the Bureau of Labor Statistics. These data are the seasonally adjusted unemployment rates reported as a percentage. ${ }^{9}$ The mean unemployment rate in the data is 5.638 percent with a standard deviation of 2.049 .

To study the relationship between a state’s monthly unemployment rates and a state’s weekly internet search activity, we estimate models of the form

$$
\text { Search }_{i t k}=\beta \text { Unemployment_rate } i t+v_{i}+\mu_{t}+\varepsilon_{i t k} \text {, }
$$

where $i$ indexes states, $t$ indexes each month-year, $k$ indexes week of the month, $S_{e a r c h} h_{i t}$ is the standardized variable for either global warming or unemployment searches, $v_{i}$ is a unique intercept for each state, $\mu_{t}$ is a unique intercept for each month-year, and $\varepsilon_{i j k}$ is a normally

\footnotetext{
${ }^{7}$ We also examined other search terms such as "climate change" but the search volume for this more nuanced term is very low.

${ }^{8}$ We exclude some observations because of a high frequency of zeros for small states such as North Dakota. In particular, we drop observations for a given week if both the global warming and unemployment search volume is zero. This leads us to drop 250 observations (only 1.8 percent of the data), and most of the dropped observations are from the year 2004, the first year that Google Insights reports search volume. We also exclude Wyoming from the analysis because of some peculiarities of the data for that state. The main results, however, do not change with inclusion of these dropped data.

${ }^{9}$ The data are available online at http://www.bls.gov/lau/.
} 
distributed error term. The coefficient of interest is $\beta$, as it provides an estimate of how, on average, changes in a state's unemployment rate affect keyword search activity within that state. Advantages of the model are that identification comes from variation within a state, after controlling for changes through time that are common to all states, such as macro-economic trends, new information, heat waves, and cultural events, e.g., Al Gore’s Nobel Prize in 2007. We estimate the models with the fixed effects estimator weighted by each state's population in 2000, and we report standard errors clustered at the state-month-year, reflecting the unit at which the unemployment data varies.

Table 1 reports the results for global warming and unemployment in columns (1) and (3). The coefficient on the unemployment-rate variable is highly statistically significant in both the global warming and unemployment models, but as hypothesized, it has the opposite sign between the two models. Higher unemployment rates decrease internet search activity for global warming, but increase search activity for unemployment. Based on this revealed preference for interest in global warming, therefore, it appears that recessions crowd out concern for the environment, while not surprisingly increasing concern about unemployment. Interestingly, the magnitudes of the coefficients are very similar despite having opposite signs, which is at least consistent with the notion that one crowds out the other.

Given the well-known ideological divide between "Red States” and "Blue States” on environmental issues, we also explore how overall state political ideology affects the association between state unemployment rates and Google searches. For each state, we collected additional data on the share of votes cast for the Democrat John Kerry in the 2004 Presidential Election. We define this variable as Kerry, and across the states it has a mean of 0.468 and standard deviation of 0.082 . With the new variable, we estimate an augmented version of the previous model: 


$$
\text { Search }_{i t k}=\beta_{1} \text { Unemployment_rate }_{i t}+\beta_{2} \text { Unemployment_rate }_{i t} \times \text { Kerry }_{i}+v_{i}+\mu_{t}+\varepsilon_{i t k} \text {, }
$$

where the coefficient on the interaction, $\beta_{2}$, indicates how the marginal effect of a state's unemployment rate on Google searches differs with different political ideology within a state. Note that Kerry $_{i}$ does not enter the model independently because, due to its time invariance, it is perfectly collinear with the state fixed effects.

Table 1 reports the augmented-model results in columns (2) and (4). The coefficient on the interaction is negative and statistically significant in both cases, though only at the 90-percent level for the unemployment model. With respect to the global-warming model, the result is interpreted such that, on average, increases in a state's unemployment rate reduce the number of Google searches for global warming within the state, but the reduction is larger in states that lean more Democratic. Hence it appears, perhaps somewhat counter-intuitively, that concern about global warming is more negatively correlated with the business cycle in states that lean democratic rather than republican. One possible explanation is that Republican concern about climate change is simply lower and less variable. With respect to the model for internet searches on unemployment, the result implies that, on average, increases in a state's unemployment increase the number of Google searches for unemployment, but the increase is lower in states that lean more Democratic. In other words, Democratic leaning states appear less responsive to declines in business cycle regarding increases in unemployment internet searches.

\section{National Survey on Public Opinion about Climate Change}

We obtained data from two surveys conducted by the Yale Project on Climate Change that were designed to gauge public opinion about global warming and related topics. The surveys were administered by Knowledge Networks and were conducted between (1) October 8 - 14, 2008 
and (2) December 24, 2009 - January 3, 2010. The nationally representative sample sizes for the two surveys are, respectively, 2,189 and 1,001 adults over the age of 18 . The two samples are independent so that no respondents are represented in both surveys. ${ }^{10}$

Our empirical strategy takes advantage of five different questions that were asked in both waves of the survey. The questions are reproduced here verbatim, along with the response categories for each and the corresponding numerical codes for our analysis:

1. Do you think global warming is happening? 1 = yes, $0=$ no or don't know. ${ }^{11}$

2. How sure are you that global warming is happening? [Asked only if response to the previous question is “yes”] $1=$ not sure at all, 2 = somewhat sure, $3=$ very sure, $4=$ extremely sure.

3. How big of an effort should the United States make to reduce global warming? 1 = no effort, 2 = a small scale effort, even if it has small economic costs, $3=$ a medium-scale effort, even if it has moderate economic costs, 4 = a large-scale effort, even if it has large economic costs.

4. How much do you support or oppose the regulation of carbon dioxide (the primary greenhouse gas) as a pollutant? 1 = strongly oppose, 2 = somewhat oppose, 3 = somewhat support, 4 = strongly support.

5. Do you think the U. S. Congress should be doing more or less to address global warming? 1 = much less, 2 = less, 3 = currently doing the right amount, $4=$ more, $5=$ much more.

\footnotetext{
${ }^{10}$ Details about the surveys and descriptive statistics beyond those reported here are available in numerous reports about survey results at http://environment.yale.edu/climate/.

${ }^{11}$ The original survey question had "no" and “don’t know" as separate response categories, but we combine the two for purposes of analysis in this paper.
} 
Additional variables taken from the surveys are socioeconomic characteristics for each respondent: annual household income, gender, age, and education. We also use the unemployment rate data (described in the previous section) corresponding with each respondent's state of residence and the month when the survey was administered.

Table 2 reports summary statistics for the pooled data. Sixty-seven percent of the respondents think that global warming in happening. Among these respondents, they tend to be "very sure" that it is happening. Respondents tend to think the U.S. should make a medium-scale effort to address global warming, even if it has moderate economic costs. They are also somewhat supportive of regulating carbon dioxide as a pollutant, and they think congress is somewhere between doing the right amount and could be doing more to address global warming. While the average statewide unemployment rate among respondents at the time they were surveyed is 7.4 percent, the rate increased from 6.3 to 9.9 percent between the two waves of the survey.

To evaluate the effect of unemployment rates on survey responses, we estimate regression models of the general form

$$
Y_{i j}=\beta_{1} \text { Unemployment_rate }_{i j}+\beta_{2} \text { Income }_{i}+\beta_{3} \text { Male }_{i}+\beta_{4} \text { Age }_{i}+\beta_{5} \text { Education }_{i}+v_{j}+\varepsilon_{i j} \text {, }
$$

where $i$ indexes respondents, $j$ indexes states, $Y_{i j}$ is the response variable for one of the survey questions, $v_{j}$ is a state-specific intercept, and $\varepsilon_{i j}$ is a normally distributed error term. Despite the fact that survey response variables are categorical, we simplify the analysis by assuming they are continuous in our specifications, though all qualitative results are robust to models with categorical response variables. The coefficient of primary interest is $\beta_{1}$, as it provides an estimate of how changes in the unemployment rate affects survey responses based on variation within each state. The other $\beta$ s estimate how changes in the socioeconomic variables affect responses, 
also based on variation within each state. In all models, we report fixed effects estimates and clustered standard errors at the state level.

Table 3 reports the results of all five models. Coefficients on the unemployment rate variable are all negative and highly statistically significant, indicating that higher unemployment within a state is associated with less concern about climate change, according to the five questions. We find that a 1-percent increase in the unemployment rate is associated with a 3.4percent decrease in the probability that a respondent thinks global warming is happening. Moreover, among those that do think it is happening, the increase in unemployment decreases confidence about their assessment. With higher unemployment, respondents also think the U.S. should be making less of an effort to reduce global warming, are less supportive of regulating carbon dioxide as a pollutant, and think congress should be doing less to address global warming. While the coefficient on income is negative in all models, it is statistically significant with respect to the effort question only; that is, somewhat counter-intuitively, respondents with higher income are more likely to respond that the U.S. should be doing less to reduce global warming if there are economic costs. Age has only a small and mostly insignificant effect. The results for Education are interesting with respect to whether respondents think global warming is happening: one more year of education is associated with nearly a 2-percent increase in the probably that one thinks global warming is happening, and more education is also associated with greater confidence in this viewpoint.

Taken together, the results in Table 3 provide robust evidence that higher unemployment rates decrease concern about climate change. The primary advantage of our empirical strategy is that these effects are identified off of changes in the unemployment rate within each state. Technically, this is possible because there are two waves of the survey, meaning that we can 
include the state fixed effects. A limitation of the models, however, is that they do not control for things that change between the two waves of the survey other than macroeconomic conditions captured by the unemployment rate. Though we do not report the results here, we did attempt to account for common effects across all states in models that include of a dummy variable for average differences between waves of the survey. These models also produce negative coefficients on the Unemployment_rate variable, but they are not statistically significant, presumably due to the fact that there is far less variation in the change in unemployment rates among states upon which to identify an effect.

\section{California Survey on Priority Issues}

The state of California is widely recognized as the leading environmental trend setter in the nation. It was the first state to pass rigorous standards in the early 1970s on vehicle emissions and energy efficiency. In 2006, California also passed the landmark AB32 bill that requires sharp reductions in the state's greenhouse gas emissions. Given the state's progressive culture and its active environmental leadership, it is compelling to ask whether California residents have continued to support environmental causes as the recession of 2008 has unfolded.

In order to address this question, we use public opinion data at the household level to test whether a county's monthly unemployment rate is negatively associated with the way households prioritize environmental concerns. Our measure of public opinion is based on micro data collected by the Public Policy Institute of California (PPIC). ${ }^{12}$ We pool repeated crosssections of the PPIC monthly surveys from January, March, April, May, August and September of 2008 along with those from January, February, March, April, and May of 2009. Omitted

\footnotetext{
${ }^{12}$ These data are available online at http://www.ppic.org/main/datadepot.asp.
} 
months are those for which the PPIC did not ask the exact policy-priority question that is central to our analysis.

In the eleven waves of the survey that we consider, each respondent was asked the following question: "Which ONE issue facing California today do you think is the MOST important?” While the actual survey includes roughly 30 categories among which respondents can choose, we aggregate the categories into 9 groups in order to reduce dimensionality of the analysis: economy, environment, jobs, education, health, immigration, deficit, taxes, and other. We also collected data on each county's unemployment rate by month from the State of California’s Employment and Development Department. ${ }^{13}$ The unemployment data were then merged with the survey data so that each respondent observation is matched with the corresponding unemployment rate at the time of the survey in his or her county of residence.

Table 4 reports descriptive statistics. These, along with the statistical models presented below, are weighted according to the PPIC weights to make the sample representative of California's population based on the sample criterion. Among the aggregated response categories, the economy is considered the most significant priority area (chosen 33 percent of the time), followed by jobs (10 percent) and education (8 percent). Environment is chosen much less frequently as the most significant priority area (less than 2 percent of the time). The mean age is 51 years, and about 50 percent have educational attainment of at least a college degree. The mean unemployment rate is 8.8 percent with a standard deviation of 3.1.

We first estimate a multinomial logit model to predict the probability that a respondent will choose each of the categories as the most important priority issue. We include all of the socioeconomic variables listed in Table 4 as explanatory variables, in addition to the unemployment rate in the respondent's county at the time of the survey. We use "economy” as

\footnotetext{
${ }^{13}$ These data are available online at http://www.labormarketinfo.edd.ca.gov/.
} 
the omitted category and report standard errors clustered at the county-month-year level, that is, the unit at which the unemployment data varies. Table 5 reports all coefficient estimates that are interpreted relative to the omitted category (economy as the priority issue, and a female respondent who did not complete high school). There is a clear demographic difference among those who prioritize environment as the state's major policy priority compared to the economy. Older people are less likely to prioritize the environment, and more education tends to increase the probability of prioritizing the environment.

After controlling for these demographics, the key finding is the negative and statistically significant coefficient on the unemployment rate. The result suggests, ceteris paribus, that higher levels of unemployment in a county are associated with respondents in that county being less likely to prioritize the environment compared to the economy. In contrast, greater unemployment rates in a county are associated with respondents in that county being significantly more likely to prioritize jobs compared to the economy. For all other issue areas, with the exception of taxes, greater unemployment rates decrease the likelihood of the issue being a priority, though it is noteworthy that the magnitudes are less than that for the environment.

To judge the size of the coefficients, we use the model to predict how changes in the unemployment rate change the average probability of prioritizing each of the different issue areas. We first generate predicted probabilities for each issue area for every observation using observed values for the demographic variables and holding the unemployment rate at its overall mean of 8.84 percent. We then repeat the same procedure but increase the unemployment rate one standard deviation, that is, 3.15 percent. The means of the predicted probabilities for both distributions are reported near the bottom on Table 5. We find, for example, that an increase in the unemployment rate of one standard deviation from the mean causes an increase in the 
probability of a respondent choosing economy as the priority issue from 33.1 to 36.0 percent. To facilitate comparison across issue areas, we also report in the last row the proportional differences. Though environment starts with a relatively low probability, the same increase in the unemployment rate decreases its probability of being the priority issue by more then 50 percent, while the increase in the probability for economy and jobs is roughly 9 and 35 percent, respectively.

The multinomial logit model provides evidence that increases in the unemployment rate within California counties affects how individuals prioritize among issue areas, but we should mention two potential concerns with the preceding empirical strategy. The first mirrors that for our analysis in Section 3: the model does not account for average effects through time that are common to all counties. Though not reported here, we did run specifications that include dummies for each wave of the survey; but just as we found for the national survey analysis, the results on unemployment are statistically insignificant when we control for unobserved and common, average time effects. Hence our interpretation of the results in Table 5 implicitly assumes that changes in unemployment are what only matters through time when estimating how local economic conditions affect how individuals prioritize the issues.

The second potential concern is that the multinomial logit model does not control for county fixed effects. As a robustness check, therefore, we estimate linear probability models (one for the choice of each priority issue) that enable us to include county fixed effects. Table 6 reports these results, excluding a model for the "other” category. The qualitative pattern of results is robust to these specifications and the inclusion of the county fixed effects. Notably, increases in the unemployment rate within a county decreases the probability that environment is chosen as the priority issue within that county, but increases the probability that either the 
economy or jobs is selected. In terms of magnitudes a 1-percent increase in the unemployment rate decreases the probability of choosing the environment by approximately half a percent, while it increase the probability of choosing the economy or jobs by 17 and 18 percent, respectively.

\section{Discussion and Conclusion}

This paper uses three different sources of data to investigate the association between the business cycle—measured with unemployment rates—and concern about climate change in particular and environmental issues in general. Building on recent research that finds internet search terms to be useful predictors of health epidemics and economic activity, we study the relationship between Google keyword searches within a state and a state's unemployment rate. We find, on average, that an increase in a state's unemployment rate decreases searches for "global warming” and increase searches for "unemployment." We also find that in more Democratic leaning states, the decline in global-warming searches is larger, but the increase in unemployment searches is smaller.

While the Google analysis provides evidence based on a revealed preference related to concern about climate change, our other evidence is based on stated preferences that ask about environmental concern directly. We take advantage of two waves of a national survey with common questions about climate change to investigate how responses differ within states based on changes in the states' unemployment rate. We find that an increase in a state's unemployment rate is associated with a decrease the probability that residents think global warming is happening, and with a reduction in the certainty of those who think it is. Higher unemployment rates are also associated with views that we should do less with respect to policies designed to 
reduce global warming. In terms of more general environmental concern, our evidence comes from eleven monthly waves of a California survey that asks respondents to indicate the issue area that they think is most important. We find that an increase in a county's unemployment rate is associated with a significant decrease is county residents choosing the environment as the most important issue area.

Together, the results presented here provide the first empirical estimates of how unemployment rates affect environmental concern. But what mechanisms are likely to underlie the results? During a recession, households are likely to focus on day-to-day well being rather than more abstract, long term, and uncertain threats such as global warming. The fear of losing one's job, along with concern for friends and family in their efforts to remain employed, are likely to focus attention on the short-run health of the economy and coping with macro uncertainty. Such behavior is consistent with psychological theory based on Maslow's (1943) hierarchy of needs. It is also consistent with our results on increasing concern about the economy and unemployment at the same time we observe decreasing concern about global warming and the environment.

Anticipating such shifts in focus, the national media has an incentive to increase coverage of the recession and decrease coverage of environmental issues like global warming. Based on data that we collected from Google News and the Vanderbilt Television News Archive, Figures 1 and 2 show trends in actual coverage of global warming and unemployment by the national media between January 2006 and January 2010. Figure 1 shows a downward trend in the number of print media stories about global warming in major national newspapers since the beginning of 2007. At the same time, the number of print media stories about unemployment exhibits an upward trend. Figure 2 reports television media coverage in terms of minutes of coverage by 
month. Note that prior to November 2007, global warming and unemployment receive a similar number of minutes, but thereafter coverage of global warming drops off (with the exception of the spike at the end of 2009 corresponding with the COP 15 meetings in Copenhagen); meanwhile coverage of unemployment is substantially higher, especially beginning in the Fall of 2008 when the recession started to take hold. We must recognize, however, that while media coverage reflects the population's priorities at a given point in time, it also influences peoples' priorities through the spread of information. This is important in the context of recent studies that emphasize the causal role of the media in determining economic and political outcomes (Besley and Burgess 2002; DellaVigna and Kaplan 2007; Eisensee and Stromberg 2007). Accordingly, future research that further investigates the causal relationship between media coverage and environmental concern would be useful.

Social interactions are also likely to play a role. It is easy to imagine multiple equilibria, whereby a population can become highly concerned about global warming and interaction with like minded friends and colleagues reinforces this world view. Cultural events, such as watching An Inconvenient Truth, may help such individuals connect in residential communities and/or on the internet. Participating in "green consumer” markets with purchases such as a Prius hybrid car, solar panels, or green power may reinforce interest and community discussion of environmental issues (Kahn 2007; Kotchen and Moore 2007, 2008). But, of course, the same phenomena can also operate in ways that diminish concern about the environment. A modification of Becker’s (1991) bandwagon model offers one possible modeling strategy; for example, one’s interest in global warming may decline if his or her peer group’s interest declines. From an empirical perspective, a recession may thus represent an exogenous shock that 
ultimately reduces concern through both individual and peer-group effects. Further research that builds on these ideas would be of value.

Finally, we conclude with emphasis on why understanding the relationship between environmental concern and recessions is important for public policy and economics. It is wellknown that public opinion affects which public policies ultimately pass and how they are funded and implemented. With this in mind, the results of this paper suggest that effective environmental policy in general and climate-change policy in particular is more likely during economic booms. At present, however, we face significant economic challenges concurrent with increasing pressure for substantive climate and energy policies at the state, national, and international levels. Whether or not something happens in the near future remains to be seen, but making the connection between the business cycle and environmental concern is a important link in the process of understanding the prospects for environmental policy and the full cost of recessions. 


\section{References}

Becker, G. S. (1991) “A Note on Restaurant Pricing and Other Examples of Social Influences on Price,” Journal of Political Economy, 99:1109-1116.

Besley, T. and R. Burgess (2002) “The Political Economy of Government Responsiveness. Theory and Evidence From India,” Quarterly Journal of Economics 117:1415-1452.

Bloom, D. E. (1995) “International Public Opinion on the Environment,” Science, 5222:354-358.

Burnstein, P. (2003) “The Impact of Public Opinion on Public Policy: A Review and an Agenda,” Political Research Quarterly, 56:29-40.

Chaoi, H. and H. Varian (2009) "Predicting the Present with Google Trends,” Working paper, Google Inc. Available at http://static.googleusercontent.com/external_content/untrusted_dlcp/www.google.com/en lus/googleblogs/pdfs/google_predicting_the_present.pdf

Chay, K. and M. Greenstone (2003) “The Impact Of Air Pollution On Infant Mortality: Evidence From Geographic Variation In Pollution Shocks Induced By A Recession,” The Quarterly Journal of Economics, 118:1121-1167.

DellaVigna, S. and E. Kaplan (2007) “The Fox News Effect: Media Bias and Voting,” Quarterly Journal of Economics, 122:1187-1234.

Dunlap, R. E. (1995) “Public Opinion and Environmental Policy,” in Environmental Politics and Policy: Theories and Evidence, J. P. Lester (ed.), Duke University Press.

Dunlap, R. E. and A. G. Mertig (1992) American Environmentalism: The U.S. Environmental Movement, 1970-1990. Taylor Francis New York Inc.

Dunlap, R. E. and A. McCright (2008) “A Widening Gap, Republican and Democratic Views on Climate Change,” Environment, 50:27-37.

Durr, R. H. (1993) “What Motivates Policy Sentiment?” American Political Science Review, 87:158-172.

Eisensee, T. and D. Stromberg (2007) "News Droughts, News Floods, and U.S Disaster Relief,” Quarterly Journal of Economics 122:693-728.

Elliott, E., J. R. Regens, and B. J. Seldon (1995) "Exploring variation in Public Support for Environmental Protection,” Social Science Quarterly, 76:41-52.

Elliot, E., B. J. Seldon, and J. L. Regens (1997) "Political and Economic Determinants of Individual's Support for Environment Spending,” Journal of Environmental Management, 51:15-27. 
Gallop Poll (2009) “American: Economy Takes Precedent Over Environment,” Report available at http://www.gallup.com/poll/116962/americans-economy-takes-precedenceenvironment.aspx.

Hilton, F. G. H. and A Levinson (1998) "Factoring the Environmental Kuznets Curve: Evidence from Automotive Lead Emissions,” Journal of Environmental Economics and Management, 35:126-141.

Kahn, M. E. (1999) “The Silver Lining of Rust Belt Manufacturing Decline.” Journal of Urban Economics, 46:360-76.

Kahn, M. E. (2007) “Do Greens Drive Hummers or Hybrids? Environmental Ideology as a Determinant of Consumer Choice,” Journal of Environmental Economics and Management, 54:129-145.

Kotchen, M. J. and M. R. Moore (2007) "Private Provision of Environmental Public Goods: Household Participation in Green-Electricity Programs,” Journal of Environmental Economics and Management, 53:1-16.

Kotchen, M. J. and M. R. Moore (2008) "Conservation: From Voluntary Restraint to a Voluntary Price Premium,” Environmental and Resource Economics, 40:195-215.

Maslow, A. H. (1943) “A Theory of Human Motivation,” Psychological Review, 50:370-396.

Page, B. I and R. Y. Shapiro (1983) “Effects of Public Opinion on Policy,” American Political Science Review, 77:175-190.

Pelat, C., C. Turbelin, A Bar-Hen, A. Flahault, and A. Valleron (2009) "More Diseases Tracked by Using Google Trends,” Emerging Infectious Diseases, 15:1327-1328.

Pew Research Center (2009) "Fewer Americans See Solid Evidence of Global Warming,” Report available at http://pewresearch.org/pubs/1386/cap-and-trade-global-warmingopinion.

Seldon, T. M. and D. Song (1995) "Neoclassical Growth. The J Curve for Abatement, and the Inverted U Curve for Pollution,” Journal of Environmental Economics and Management, 29:162-168.

Shanahan, J., M. Morgan, and S. Mads (1997) "Green or Brown? Television and the Cultivation of Environmental Concern,” Journal of Broadcasting and Electronic Media, 41:305-324.

Valdivia, A. and S. Monge-Corella (2010) “Diseases Tracked by Using Google Trends, Spain,” Emerging Infectious Diseases, 16:168. 
Van Liere, K. D. and R. E. Dunlop (1980) “The Social Bases of Environmental Concern: A Review of Hypotheses, Explanations and Empirical Evidence,” Public Opinion Quarterly, 44:181-197.

Vogel, D. (1989) Fluctuating Fortunes. New York: Basic Books. 
Total Monthly Count of Stories Mentioning Respective Keyword

(WSJ + USA Today + NY Times + LA Times + WaPo)

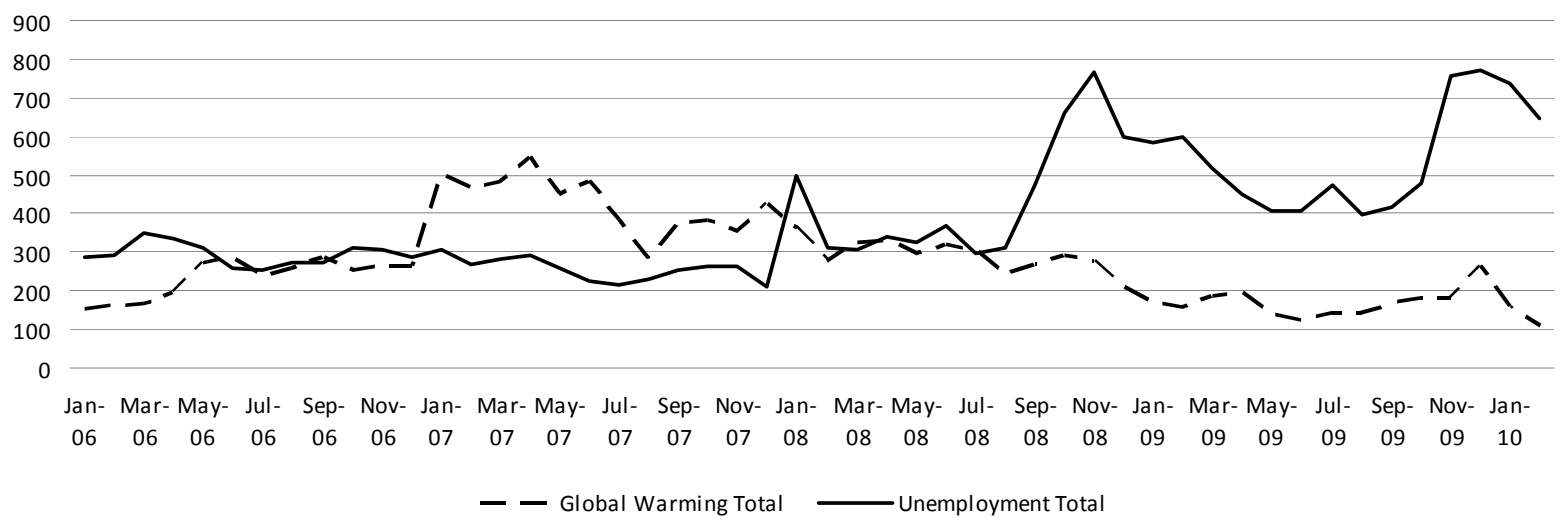

Figure 1: Print media coverage of "global warming" and "unemployment." Data collected using keyword searches in Google news (http://news.google.com/nwshp?hl=en\&tab=wn) and summing the number of stories listed by month in the 5 major newspapers with national coverage.

Total Minutes of Monthly Television New Coverage $(A B C+C B S+C N N+F O X+N B C)$

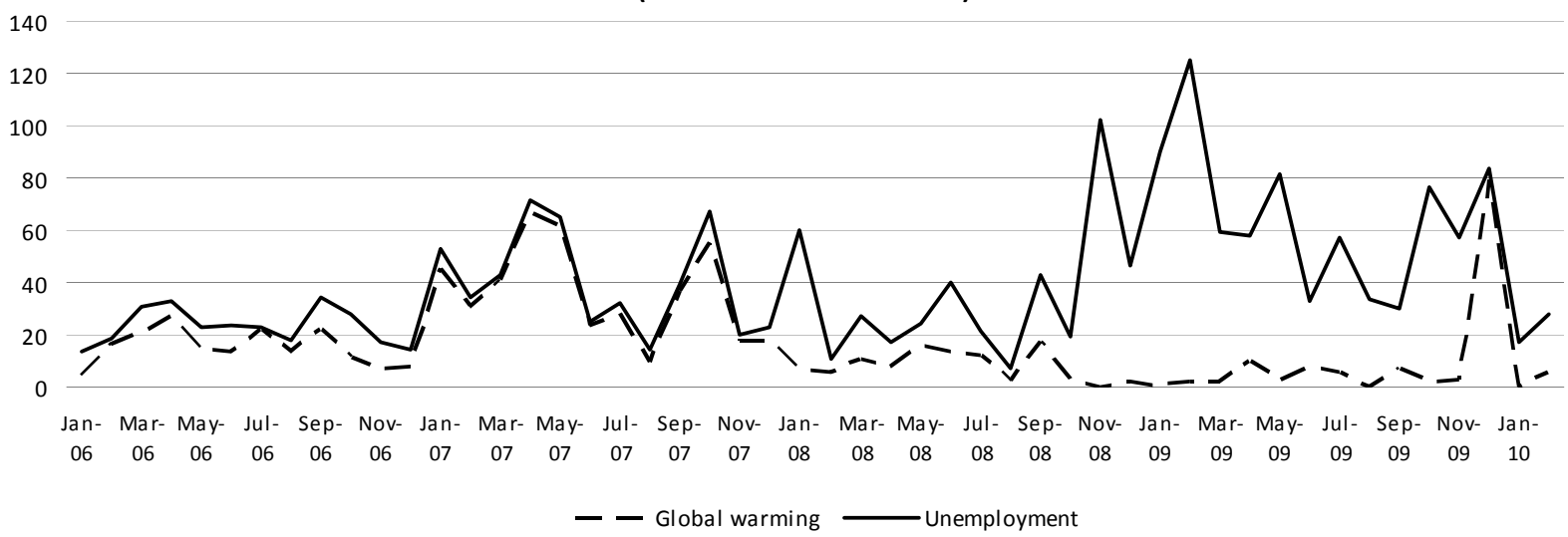

Figure 2: Television coverage of "global warming" and "unemployment." Data collected using keyword searches in the Vanderbilt Television News Archive (http://tvnews.vanderbilt.edu/) and summing the number of coverage minutes by month for all 5 national networks. 
Table 1: Fixed effects models of Google keyword searches

\begin{tabular}{|c|c|c|c|c|}
\hline & \multicolumn{2}{|c|}{ Global warming } & \multicolumn{2}{|c|}{ Unemployment } \\
\hline & $(1)$ & $(2)$ & $(3)$ & $(4)$ \\
\hline Unemployment_rate & $\begin{array}{c}-0.052^{* * *} \\
(0.012)\end{array}$ & $\begin{array}{c}0.238^{\star * *} \\
(0.027)\end{array}$ & $\begin{array}{c}0.060^{* * *} \\
(0.019)\end{array}$ & $\begin{array}{c}0.122^{\star * *} \\
(0.040)\end{array}$ \\
\hline Unemployment_rate $\times$ Kerry & -- & $\begin{array}{c}-0.575^{\star \star \star} \\
(0.057)\end{array}$ & -- & $\begin{array}{l}-0.123^{\star} \\
(0.072)\end{array}$ \\
\hline Constant & $\begin{array}{c}-0.677^{\star \star \star} \\
(0.096)\end{array}$ & $\begin{array}{c}-0.723^{* \star *} \\
(0.086)\end{array}$ & $\begin{array}{c}-0.474^{\star \star \star} \\
(0.158)\end{array}$ & $\begin{array}{c}-0.484^{\star \star \star} \\
(0.156)\end{array}$ \\
\hline Month-year dummies & Yes & Yes & Yes & Yes \\
\hline State fixed effects & Yes & Yes & Yes & Yes \\
\hline$R$-squared (adjusted) & 0.730 & 0.735 & 0.919 & 0.919 \\
\hline
\end{tabular}

Notes: All models are based on 13,890 observations. The dependent variables are relative frequency of Google searches for the corresponding keyword standardized by keyword and state. The mean for Unemployment rate is 5.638 , and the mean for Kerry is 0.468 . Standard errors clustered at the state-month-year are reported in parentheses. Three, two, and one asterisk(s) indicate statistical significance at the 99-, 95- and 90-percent levels, respectively.

Table 2: Summary statistics for climate change survey analysis

\begin{tabular}{|c|c|c|c|}
\hline Variable & Mean & Std. Dev. & Observations \\
\hline Do you think global warming is happening? & 0.668 & $(0.471)$ & 3149 \\
\hline $\begin{array}{l}\text { How sure are you that global warming is } \\
\text { happening? }\end{array}$ & 2.955 & $(0.876)$ & 2075 \\
\hline $\begin{array}{l}\text { How big of an effort should the U.S. make to } \\
\text { reduce global warming? }\end{array}$ & 2.892 & $(0.979)$ & 3087 \\
\hline $\begin{array}{l}\text { How much do you support or oppose the } \\
\text { regulation of carbon dioxide as a pollutant? }\end{array}$ & 2.956 & $(0.888)$ & 3052 \\
\hline $\begin{array}{l}\text { Do you think the U.S. Congress should be } \\
\text { doing more or less to address global warming? }\end{array}$ & 3.604 & (1.184) & 3078 \\
\hline Income & $\$ 59,894$ & $(44,070)$ & 3165 \\
\hline Male (1 = yes) & 0.483 & $(0.500)$ & 3165 \\
\hline Age & 46.3 & (16.8) & 3165 \\
\hline Education (years) & 13.4 & $(2.7)$ & 3165 \\
\hline Unemployment_rate & 7.421 & (2.181) & 3152 \\
\hline
\end{tabular}


Table 3: Fixed effects models of how changes in the unemployment rate affects responses to climate change questions

\begin{tabular}{|c|c|c|c|c|c|}
\hline & (1) & (2) & (3) & (4) & (5) \\
\hline & $\begin{array}{c}\text { Do you think } \\
\text { global } \\
\text { warming is } \\
\text { happening? }\end{array}$ & $\begin{array}{c}\text { How sure are } \\
\text { you that } \\
\text { global } \\
\text { warming is } \\
\text { happening? }\end{array}$ & $\begin{array}{l}\text { How big of an } \\
\text { effort should } \\
\text { the U.S. } \\
\text { make to } \\
\text { reduce global } \\
\text { warming? }\end{array}$ & $\begin{array}{l}\text { How much do } \\
\text { you support or } \\
\text { oppose the } \\
\text { regulation of } \\
\text { carbon dioxide } \\
\text { as a pollutant? }\end{array}$ & $\begin{array}{l}\text { Do you think the } \\
\text { U.S. Congress } \\
\text { should be doing } \\
\text { more or less to } \\
\text { address global } \\
\text { warming? }\end{array}$ \\
\hline Unemployment_rate & $\begin{array}{c}-0.034^{\star \star \star} \\
(0.006)\end{array}$ & $\begin{array}{c}-0.061^{\star \star *} \\
(0.015)\end{array}$ & $\begin{array}{c}-0.075^{\star \star \star} \\
(0.014)\end{array}$ & $\begin{array}{c}-0.057^{\star \star \star} \\
(0.011)\end{array}$ & $\begin{array}{c}-0.104^{\star \star \star} \\
(0.016)\end{array}$ \\
\hline Income $(\$ 10,000 s)$ & $\begin{array}{l}-0.003 \\
(0.003)\end{array}$ & $\begin{array}{l}-0.001 \\
(0.007)\end{array}$ & $\begin{array}{c}-0.013^{\star *} \\
(0.006)\end{array}$ & $\begin{array}{l}-0.007 \\
(0.006)\end{array}$ & $\begin{array}{l}-0.018 \\
(0.011)\end{array}$ \\
\hline Male (1 = yes) & $\begin{array}{c}-0.048^{\star *} \\
(0.020)\end{array}$ & $\begin{array}{l}-0.008 \\
(0.045)\end{array}$ & $\begin{array}{c}-0.173^{\star \star \star *} \\
(0.050)\end{array}$ & $\begin{array}{c}-0.154^{\star \star *} \\
(0.042)\end{array}$ & $\begin{array}{c}-0.173^{\star \star \star} \\
(0.054)\end{array}$ \\
\hline Age & $\begin{array}{c}-0.000 \\
(0.001)\end{array}$ & $\begin{array}{c}0.001 \\
(0.002)\end{array}$ & $\begin{array}{c}0.002 \\
(0.001)\end{array}$ & $\begin{array}{l}0.002^{\star} \\
(0.001)\end{array}$ & $\begin{array}{c}0.001 \\
(0.002)\end{array}$ \\
\hline Education (years) & $\begin{array}{c}0.018^{\star \star \star} \\
(0.004)\end{array}$ & $\begin{array}{l}0.028^{\star *} \\
(0.011)\end{array}$ & $\begin{array}{c}0.010 \\
(0.011)\end{array}$ & $\begin{array}{c}0.013 \\
(0.008)\end{array}$ & $\begin{array}{l}0.029 * * \\
(0.012)\end{array}$ \\
\hline Constant & $\begin{array}{c}0.732^{\star * *} \\
(0.078)\end{array}$ & $\begin{array}{c}2.999 * \star \star \\
(0.250)\end{array}$ & $\begin{array}{c}3.369 * * * \\
(0.175)\end{array}$ & $\begin{array}{c}3.211^{* * *} \\
(0.149)\end{array}$ & $\begin{array}{c}4.113^{\star * *} \\
(0.200)\end{array}$ \\
\hline $\begin{array}{l}\text { State dummies } \\
\text { Observations } \\
R \text {-squared }\end{array}$ & $\begin{array}{l}\text { Yes } \\
3,137 \\
0.061\end{array}$ & $\begin{array}{c}\text { Yes } \\
2,068 \\
0.069\end{array}$ & $\begin{array}{c}\text { Yes } \\
3,076 \\
0.066 \\
\end{array}$ & $\begin{array}{l}\text { Yes } \\
3,041 \\
0.054\end{array}$ & $\begin{array}{c}\text { Yes } \\
3,067 \\
0.069\end{array}$ \\
\hline
\end{tabular}

Notes: Codes for response categories to each question are reported in the main text. Standard errors clustered at the state level are reported in parentheses. Three, two, and one asterisk(s) indicate statistical significance at the 99-, 95- and 90-percent levels, respectively. 
Table 4: Summary statistics for the California policy-priorities 2008 and 2009

\begin{tabular}{lcc}
\hline \hline Variable & Mean & Std. Dev. \\
\hline Priority issue & & \\
Economy & 0.325 & $(0.468)$ \\
Environment & 0.017 & $(0.128)$ \\
Jobs & 0.101 & $(0.302)$ \\
Education & 0.084 & $(0.277)$ \\
Health & 0.030 & $(0.172)$ \\
Immigration & 0.068 & $(0.253)$ \\
Deficit & 0.072 & $(0.259)$ \\
Taxes & 0.024 & $(0.153)$ \\
Other & 0.279 & $(0.448)$ \\
Socioeconomic characteristics & & \\
Age & 51.155 & $(17.144)$ \\
Male (1 = yes) & 0.488 & $(0.500)$ \\
Less than high school degree & 0.135 & $(0.342)$ \\
High school & 0.191 & $(0.393)$ \\
College & 0.248 & $(0.432)$ \\
Post-graduate & 0.246 & $(0.431)$ \\
County level & & \\
Unemployment_rate & 8.810 & $(3.137)$ \\
\hline \hline Notes: Statistics are weighted and based on 22,983 & \\
observations. & &
\end{tabular}


Table 5: Multinomial logit estimates of California respondent's policy priorities in 2008 and 2009

\begin{tabular}{|c|c|c|c|c|c|c|c|c|c|}
\hline & (1) & (2) & (3) & $(4)$ & (5) & (6) & $(7)$ & $(8)$ & $(9)$ \\
\hline & Economy & Environment & Jobs & Education & Health & Immigration & Deficit & Taxes & Other \\
\hline Unemployment_rate (county) & -- & $\begin{array}{l}-0.254^{\star \star \star} \\
(0.027)\end{array}$ & $\begin{array}{c}0.072^{\star \star \star} \\
(0.011)\end{array}$ & $\begin{array}{l}-0.137^{\star \star \star} \\
(0.022)\end{array}$ & $\begin{array}{c}-0.133^{\star \star \star} \\
(0.025)\end{array}$ & $\begin{array}{l}-0.173^{\star \star \star} \\
(0.020)\end{array}$ & $\begin{array}{l}-0.057^{\star \star} \\
(0.027)\end{array}$ & $\begin{array}{c}0.024 \\
(0.022)\end{array}$ & $\begin{array}{c}-0.025^{\star \star \star} \\
(0.010)\end{array}$ \\
\hline Age & -- & $\begin{array}{l}-0.012^{* * *} \\
(0.003)\end{array}$ & $\begin{array}{l}-0.004^{\star *} \\
(0.002)\end{array}$ & $\begin{array}{l}-0.012^{* * *} \\
(0.002)\end{array}$ & $\begin{array}{c}0.001 \\
(0.003)\end{array}$ & $\begin{array}{l}0.011^{\star \star \star} \\
(0.002)\end{array}$ & $\begin{array}{l}0.018^{\star \star \star} \\
(0.002)\end{array}$ & $\begin{array}{l}0.012^{\star \star *} \\
(0.003)\end{array}$ & $\begin{array}{l}0.007^{\star \star \star} \\
(0.001)\end{array}$ \\
\hline Male (1 = yes) & -- & $\begin{array}{c}0.007 \\
(0.096)\end{array}$ & $\begin{array}{c}0.046 \\
(0.042)\end{array}$ & $\begin{array}{l}-0.495^{\star \star \star} \\
(0.048)\end{array}$ & $\begin{array}{l}-0.458^{\star \star \star} \\
(0.080)\end{array}$ & $\begin{array}{c}0.021 \\
(0.055)\end{array}$ & $\begin{array}{l}0.494^{* \star *} \\
(0.054)\end{array}$ & $\begin{array}{l}0.499 * \star \star \\
(0.089)\end{array}$ & $\begin{array}{l}0.220^{* \star *} \\
(0.034)\end{array}$ \\
\hline High School & -- & $\begin{array}{l}0.667^{\star \star} \\
(0.289)\end{array}$ & $\begin{array}{l}-0.232^{\star \star \star} \\
(0.090)\end{array}$ & $\begin{array}{l}0.521^{\star \star \star} \\
(0.104)\end{array}$ & $\begin{array}{l}0.796^{\star \star *} \\
(0.220)\end{array}$ & $\begin{array}{l}0.320^{\star * *} \\
(0.123)\end{array}$ & $\begin{array}{l}1.726^{* * *} \\
(0.215)\end{array}$ & $\begin{array}{l}1.552^{\star * *} \\
(0.277)\end{array}$ & $\begin{array}{l}0.315^{\star \star *} \\
(0.075)\end{array}$ \\
\hline Some College & -- & $\begin{array}{l}1.358^{\star \star \star *} \\
(0.272)\end{array}$ & $\begin{array}{l}-0.559 * \star \star * \\
(0.074)\end{array}$ & $\begin{array}{l}0.729 * \star \star \\
(0.138)\end{array}$ & $\begin{array}{c}0.762^{\star \star *} \\
(0.202)\end{array}$ & $\begin{array}{l}0.453^{\star \star *} \\
(0.121)\end{array}$ & $\begin{array}{l}2.139 * \star \star \\
(0.212)\end{array}$ & $\begin{array}{l}1.686^{\star \star \star} \\
(0.254)\end{array}$ & $\begin{array}{l}0.215^{\star \star \star} \\
(0.074)\end{array}$ \\
\hline College & -- & $\begin{array}{l}1.577^{* \star *} \\
(0.257)\end{array}$ & $\begin{array}{l}-0.777^{* * *} \\
(0.090)\end{array}$ & $\begin{array}{l}0.746 * \star * \\
(0.145)\end{array}$ & $\begin{array}{l}0.772^{\star * *} \\
(0.172)\end{array}$ & $\begin{array}{c}0.182 \\
(0.121)\end{array}$ & $\begin{array}{l}2.523^{* * *} \\
(0.204)\end{array}$ & $\begin{array}{l}1.705^{\star \star *} \\
(0.258)\end{array}$ & $\begin{array}{c}0.056 \\
(0.086)\end{array}$ \\
\hline Post-Graduate & -- & $\begin{array}{l}1.531^{\star * *} \\
(0.260)\end{array}$ & $\begin{array}{l}-1.266^{* \star \star} \\
(0.106)\end{array}$ & $\begin{array}{l}0.931^{* \star *} \\
(0.151)\end{array}$ & $\begin{array}{l}0.377^{*} \\
(0.222)\end{array}$ & $\begin{array}{l}-0.145 \\
(0.134)\end{array}$ & $\begin{array}{c}2.456^{\star \star *} \\
(0.214)\end{array}$ & $\begin{array}{l}1.785^{\star \star *} \\
(0.248)\end{array}$ & $\begin{array}{l}-0.240^{* *} \\
(0.098)\end{array}$ \\
\hline Constant & -- & $\begin{array}{l}-1.600^{* \star \star} \\
(0.337)\end{array}$ & $\begin{array}{c}-1.185^{\star \star \star} \\
(0.149)\end{array}$ & $\begin{array}{l}-0.055 \\
(0.221)\end{array}$ & $\begin{array}{c}-1.716^{\star \star \star} \\
(0.346)\end{array}$ & $\begin{array}{l}-0.898^{* \star \star} \\
(0.277)\end{array}$ & $\begin{array}{l}-4.357^{\star \star \star} \\
(0.315)\end{array}$ & $\begin{array}{l}-5.261^{\star \star \star} \\
(0.293)\end{array}$ & $\begin{array}{c}-0.462^{\star \star \star} \\
(0.152)\end{array}$ \\
\hline $\begin{array}{l}\text { Predicted Prob (Mean } \\
\text { Unemployment_rate) }\end{array}$ & 0.331 & 0.014 & 0.098 & 0.081 & 0.030 & 0.064 & 0.073 & 0.024 & 0.285 \\
\hline $\begin{array}{l}\text { Predicted Prob (Mean } \\
\text { Unemployment_rate + } 1 \mathrm{SD} \text { ) }\end{array}$ & 0.360 & 0.007 & 0.132 & 0.058 & 0.021 & 0.040 & 0.067 & 0.029 & 0.286 \\
\hline Proportional difference & 0.087 & -0.506 & 0.349 & -0.289 & -0.280 & -0.368 & -0.080 & 0.181 & 0.002 \\
\hline
\end{tabular}

Notes: The model includes 22,983 observations. The model is weighted according to PPIC weights to make the sample representative of the state's population. The overall mean of Unemployment rate is 8.810 and one standard deviation is 3.14. Standard errors clustered at the county-month-year level are reported in parentheses. Three, two, and one asterisk(s) indicate statistical significance at the 99-, 95- and 90percent levels, respectively. 
Table 6: Linear probability models with fixed effects of California respondent's policy priorities in 2008 and 2009

\begin{tabular}{|c|c|c|c|c|c|c|c|c|}
\hline & $(1)$ & $(2)$ & (3) & (4) & $(5)$ & (6) & $(7)$ & $(8)$ \\
\hline & Economy & Environment & Jobs & Education & Health & Immigration & Deficit & Taxes \\
\hline Unemployment_rate (county) & $\begin{array}{r}0.018^{\star \star \star} \\
(0.002)\end{array}$ & $\begin{array}{c}-0.004^{\star \star *} \\
(0.000)\end{array}$ & $\begin{array}{c}0.018 * \star \star \\
(0.003)\end{array}$ & $\begin{array}{c}-0.009 * * * \\
(0.002)\end{array}$ & $\begin{array}{c}-0.005^{\star \star \star} \\
(0.001)\end{array}$ & $\begin{array}{c}-0.013^{\star \star \star} \\
(0.001)\end{array}$ & $\begin{array}{l}-0.003 \\
(0.002)\end{array}$ & $\begin{array}{l}-0.003 \\
(0.002)\end{array}$ \\
\hline Age & $\begin{array}{c}-0.001^{* *} \\
(0.000)\end{array}$ & $\begin{array}{c}-0.000^{* * *} \\
(0.000)\end{array}$ & $\begin{array}{c}-0.001^{\star \star *} \\
(0.000)\end{array}$ & $\begin{array}{c}-0.001^{\star \star \star} \\
(0.000)\end{array}$ & $\begin{array}{c}0 \\
(0.000)\end{array}$ & $\begin{array}{r}0.001 * * * \\
(0.000)\end{array}$ & $\begin{array}{r}0.001 * * * \\
(0.000)\end{array}$ & $\begin{array}{r}0.001^{* \star *} \\
(0.000)\end{array}$ \\
\hline Male (1 = yes) & $\begin{array}{c}-0.022^{\star \star *} \\
(0.006)\end{array}$ & $\begin{array}{c}0.001 \\
(0.002)\end{array}$ & $\begin{array}{c}0.003 \\
(0.004)\end{array}$ & $\begin{array}{c}-0.043^{\star \star \star} \\
(0.004)\end{array}$ & $\begin{array}{c}-0.015^{\star \star \star} \\
(0.003)\end{array}$ & $\begin{array}{l}-0.003 \\
(0.003)\end{array}$ & $\begin{array}{r}0.029 * * * \\
(0.004)\end{array}$ & $\begin{array}{r}0.029 * \star \star \\
(0.004)\end{array}$ \\
\hline High School & $\begin{array}{c}-0.055^{\star \star \star} \\
(0.013)\end{array}$ & $\begin{array}{c}0.002 \\
(0.003)\end{array}$ & $\begin{array}{c}-0.067^{\star \star *} \\
(0.011)\end{array}$ & $\begin{array}{c}0.024^{\star * \star} \\
(0.006)\end{array}$ & $\begin{array}{r}0.013^{\star \star \star} \\
(0.005)\end{array}$ & $\begin{array}{c}0.007 \\
(0.007)\end{array}$ & $\begin{array}{c}0.024^{* * *} \\
(0.005)\end{array}$ & $\begin{array}{l}0.024^{\star \star \star} \\
(0.005)\end{array}$ \\
\hline Some College & $\begin{array}{c}-0.051^{* \star *} \\
(0.012)\end{array}$ & $\begin{array}{r}0.012^{\star \star \star} \\
(0.004)\end{array}$ & $\begin{array}{c}-0.103^{\star \star \star} \\
(0.010)\end{array}$ & $\begin{array}{r}0.040 * * * \\
(0.006)\end{array}$ & $\begin{array}{c}0.012^{\star \star \star} \\
(0.004)\end{array}$ & $\begin{array}{l}0.016 * \star \\
(0.006)\end{array}$ & $\begin{array}{r}0.045^{\star * \star} \\
(0.006)\end{array}$ & $\begin{array}{r}0.045^{\star \star \star} \\
(0.006)\end{array}$ \\
\hline College & $\begin{array}{c}-0.042^{\star \star \star} \\
(0.013)\end{array}$ & $\begin{array}{r}0.018 * \star \star \\
(0.004)\end{array}$ & $\begin{array}{c}-0.121^{* * *} \\
(0.010)\end{array}$ & $\begin{array}{c}0.045^{\star \star \star} \\
(0.006)\end{array}$ & $\begin{array}{c}0.015^{\star \star \star} \\
(0.003)\end{array}$ & $\begin{array}{c}0.01 \\
(0.006)\end{array}$ & $\begin{array}{r}0.081 * * * \\
(0.009)\end{array}$ & $\begin{array}{r}0.081^{\star \star \star} \\
(0.009)\end{array}$ \\
\hline Post-Graduate & $\begin{array}{l}-0.007 \\
(0.013)\end{array}$ & $\begin{array}{r}0.016 * \star \star \\
(0.003)\end{array}$ & $\begin{array}{c}-0.142^{\star \star \star} \\
(0.010)\end{array}$ & $\begin{array}{r}0.073^{\star * \star} \\
(0.008)\end{array}$ & $\begin{array}{l}0.008^{\star *} \\
(0.004)\end{array}$ & $\begin{array}{l}-0.003 \\
(0.006)\end{array}$ & $\begin{array}{r}0.091 * * * \\
(0.010)\end{array}$ & $\begin{array}{r}0.091^{\star \star \star} \\
(0.010)\end{array}$ \\
\hline Constant & $\begin{array}{r}0.238^{\star * *} \\
(0.030)\end{array}$ & $\begin{array}{r}0.055^{\star * *} \\
(0.006)\end{array}$ & $\begin{array}{c}0.065^{* * *} \\
(0.020)\end{array}$ & $\begin{array}{r}0.200^{\star * *} \\
(0.015)\end{array}$ & $\begin{array}{r}0.077^{\star * *} \\
(0.010)\end{array}$ & $\begin{array}{r}0.143^{* * *} \\
(0.013)\end{array}$ & $\begin{array}{l}-0.023 \\
(0.022)\end{array}$ & $\begin{array}{l}-0.023 \\
(0.022)\end{array}$ \\
\hline County fixed effects & Yes & Yes & Yes & Yes & Yes & Yes & Yes & Yes \\
\hline$R$-Squared & 0.015 & 0.017 & 0.047 & 0.029 & 0.014 & 0.027 & 0.035 & 0.035 \\
\hline
\end{tabular}

